\title{
Evaluation of life satisfaction and functional fitness of people over 60 years of age living in a nursing home and home environment
}

EWA KUPCEWICZ ${ }^{\text {A-F }}$, TERESA WRÓBLEWSKA ${ }^{\text {A-F }}$, ALINA KĘDZIAD-F, IWONA WOŁOSEWICZ ${ }^{\text {D-F }}$

Department of Nursing, Faculty of Medical Sciences, University of Warmia and Mazury

in Olsztyn

A - Study Design, B - Data Collection, C - Statistical Analysis, D - Data Interpretation, E - Manuscript Preparation, $\mathbf{F}$ - Literature Search, $\mathbf{G}$ - Funds Collection

Summary Background. Life satisfaction may refer to one's life evaluation, social skills and engagement in life activities. Objectives. Evaluation of life satisfaction and functional fitness of people over 60 years of age living in a nursing home and home environment.

Material and methods. A survey research was conducted at the turn of 2013 and 2014 in a group of 101 subjects over 60 years of age. This group comprised of 50 residents of the "Kombatant" nursing home in Ciechanow and 51 subjects staying in a home environment. In the research, the Satisfaction With Life Scale (SWLS) and Barthel Scale were used.

Results. Analysis of the results shows that the mean index of satisfaction with life among all subjects reached $20.7 \pm 6.21$ with a median of 23, which indicated an average level of satisfaction with life. In a home environment, 50.98\% of the subjects reported a high level of satisfaction with life as compared to only $20 \%$ in the nursing home. As for evaluation of functional fitness, more than half of the subjects (53.47\%) scored 21 to 85 points according to the Barthel Scale, and their condition was determined as "moderate to severe". A high positive correlation $(r=0.7)$ was also observed between the functional state described as "moderate to severe" among the subjects staying in a home environment and their satisfaction with life.

Conclusions. In the researched group, the level of satisfaction with life varied, with lower results among the residents of the nursing home, whereas for those living in a home environment, functional fitness was the key factor in its determination. Key words: satisfaction with life, functional fitness, resident.

Kupcewicz E, Wróblewska T, Kędzia A, Wołosewicz I. Evaluation of life satisfaction and functional fitness of people over 60 years of age living in a nursing home and home environment. Fam Med Prim Care Rev 2016; 18(4): 437-442, doi: 10.5114/ fmpcr.2016.63698.

\section{Background}

Ageing is a complex process which is determined by numerous factors and has a highly individualized character [1]. It is perceived as a destructive, progressing and irreversible process that results from biological factors connected with physical involution, as well as psychosocial factors. With age, physical and psychological fitness decrease significantly [2]. Therefore, old age is the effect of the biological, cognitive, emotional and social ageing process of a person [3]. The most common definition of old age, which was formulated by the World Health Organization (WHO) and is accepted in the present study, specifies that the period of old age begins at the age of 60 [4]. In literature on the subject, one can distinguish various factors influencing the quality of life of elderly people, such as: physical, emotional, intellectual and social functioning, satisfaction with life, health condition, economic status, sexual activity, vitality, energy and manner of spending free time [5, 6]. Numerous authors who investigate the issue of positive ageing mention satisfaction with life, intellectual efficacy, active engagement in life, lack of disability and independent functioning, as well as positive adaptation to the process of ageing [7]. Well-being constitutes an essential element of health; in fact, these two are often equated. Health condition is frequently reflected in one's subjective sense of well-being, which includes both emotional and cognitive aspects. These, in turn, are measured in the form of general satisfaction with life $[8,9]$. Shin and Johnson define satisfaction with life as a "general evaluation of quality of life in reference to personally selected criteria" [10]. According to Juczyński, "evaluation of satisfaction with life results from comparing one's own situation with one's set standards. If this result is satisfactory, its effect is a feeling of satisfaction" [8]. The results of studies clearly indicate that the level of physical fitness and quality of life of elderly people are strongly correlated $[1,11]$. However, these results are not very optimistic. Bień points to the fact that a lack of physical fitness among Poles constitutes the basic problem when considering health and social categories $[11,12]$. Negative health behaviors, computerization of life and development of the automotive industry constitute the basic causes of decreased fitness. What is more, the progress of civilization, despite its various benefits, brings about many negative effects upon society [11]. Many elderly people cannot count on the help and support of their immediate family, and consequently, the number of people who are unable to function independently and who require the care of third parties is increasing. The consequence of this situation is a growing demand for institutional care. The situation of elderly people who (for numerous reasons) are forced to live in a nursing home is very specific. A nursing home 
is a facility providing assistance to individuals who require $24 / 7$ care due to their age, disability or illness, as well as for those unable to function independently in a home environment and where it is impossible to provide the necessary care services in their place of residence $[5,13]$.

\section{Objectives}

The major goal of the present research was to evaluate the level of satisfaction with life and functional fitness of people over 60 years of age living in a nursing home and a home environment.

\section{Material and methods}

A survey was conducted at the turn of 2013 and 2014 in a group of 101 subjects over 60 years of age. This group comprised 50 residents of the "Kombatant" nursing home in Ciechanow and 51 subjects staying in a home environment. The age of the subjects ranged from 60 to 85 , and the mean was 72.98 years $( \pm 6.46)$ with a median of 73 years. The subject group included 52 females $(52.49 \%)$ and 49 males $(48.51 \%)$. The most numerous group among subjects, i.e. $43.56 \%$, was widowed $(n=44)$. The majority of subjects had higher education, i.e. $38.61 \%(n=39)$, and primary education, i.e. $32.67 \%(n=33)$. A high percentage of the residents $(44 \%)$ had lived in the nursing home for 6 years or more (Table 1).

In the present study, a self-constructed survey containing questions on basic socio-demographic data and the Satisfaction with Life Scale (SWLS) by Ed Diener, Robert A. Emmons, Randy J. Larsen and Sharon Griffin were used (Polish adaptation: Z. Juczyński) [8]. The SWLS comprises 5 statements that define satisfaction with one's achievements, and the subjects were to respond using a scale of $1-7$. All points were then added up, and the total score determined the level of satisfaction with one's life. The scope of results ranged from 5 to 35 points. The higher the score, the more the person agreed with a particular statement. Afterwards, the raw data was converted into standardized units on the sten scale. Stens in the range of 1-4 implied a low score, while those ranging 7-10 were treated as high [8].

In order to determine the level of independence of the subjects, as well as the scope of required care, the Barthel Scale questionnaire constructed by D. Barthel was used (also known as the Barthel Index). This scale helped to evaluate the ability to independently perform ten daily activities. The results ranged from 0 to 100 points. On the basis of the results obtained with the Barthel Scale, the subjects were divided into three groups depending on their psychomotor state. Individuals classified as group I obtained 86-100 points, and their condition was defined as "mild". Group II included subjects who obtained 21-85 points, and their condition was referred to as "moderate to severe", whereas group III comprised subjects with the lowest score (less than 20), and their condition was evaluated as "very severe" [14].

A descriptive analysis was used to evaluate the results. Measurable parameters were characterized by estimating the mean value and standard deviation, whereas nonmeasurable parameters were determined with the use of their number and the turnover of patients in classes. To evaluate the diversification of mean values of the researched characteristics in class variables grouping the patients, the $\cup$ Mann-Whitney test was used. The dependency of analyzed characteristics (satisfaction with life vs. functional fitness of the subjects) was verified using the Pearson productmoment correlation coefficient with a level of significance $p<0.05$. The collected data was analyzed statistically with the use of Statistica $10 \mathrm{PL}$ statistical package.

\section{Results}

Analysis of the descriptive statistics indicated that the results for the entire group of subjects ranged from 7 to 33 , and the mean score of satisfaction with life reached $20.7 \pm 6.21$

\begin{tabular}{|c|c|c|c|c|c|c|}
\hline \multirow[t]{2}{*}{ Variables } & \multicolumn{2}{|c|}{$\begin{array}{l}\text { Group } 1 \text { - residents of the } \\
\text { nursing home }\end{array}$} & \multicolumn{2}{|c|}{$\begin{array}{l}\text { Group } 2 \text { - residents staying in } \\
\text { a home environment }\end{array}$} & \multicolumn{2}{|l|}{ In total } \\
\hline & $n=50$ & $\%$ & $n=51$ & $\%$ & $n=101$ & $\%$ \\
\hline \multicolumn{7}{|l|}{ Gender } \\
\hline Female & 28 & 56.00 & 24 & 47.06 & 52 & 52.49 \\
\hline Male & 22 & 44.00 & 27 & 52.94 & 49 & 48.51 \\
\hline \multicolumn{7}{|l|}{ Marital status } \\
\hline Single & 2 & 4.00 & - & - & 2 & 1.98 \\
\hline Married & 12 & 24.00 & 22 & 43.14 & 34 & 33.66 \\
\hline Widowed & 20 & 40.00 & 24 & 47.06 & 44 & 43.56 \\
\hline Divorced & 16 & 32.00 & 5 & 9.80 & 21 & 20.79 \\
\hline \multicolumn{7}{|l|}{ Education } \\
\hline Primary & 17 & 34.00 & 16 & 31.37 & 33 & 32.67 \\
\hline Vocational & 13 & 26.00 & 13 & 25.49 & 26 & 25.74 \\
\hline Secondary & 19 & 38.00 & 20 & 39.21 & 39 & 38.61 \\
\hline Higher & 1 & 2.00 & 2 & 3.92 & 3 & 2.97 \\
\hline \multicolumn{7}{|c|}{ Length of stay in the nursing home } \\
\hline less than 1 year & 4 & 8.00 & & & & \\
\hline $1-3$ years & 13 & 26.00 & & & & \\
\hline $4-5$ years & 11 & 22.00 & & & & \\
\hline 6 years or more & 22 & 44.00 & & & & \\
\hline
\end{tabular}


with a median of 23, which denoted an average level of satisfaction with life. Moreover, statistically significant differences were observed for residents of the nursing home and a home environment in the case of four SWLS statements. While replying to the statement «In many respects, my life is almost ideal" and "If I could live my life again, I would not change anything", individuals living in a home environment obtained higher results, which were statistically significant at a level of $p=0.001$. For the statement "My living conditions are perfect", those living in a home environment also had higher results than the residents of the nursing home, and the level of statistical significance was $p=0.002$, while for the statement "I am satisfied with my life", it reached $p=0.022$ (Table 2).

In order to determine the number of low, average and high scores, the results were calculated using the appropriate sten scale (SWLS: temporary Polish norms - adults 1998-1999) [8]. Over one third of the subjects $(35.64 \% ; n=36$ ) declared a high level of satisfaction with life, and over one third a low level $(34.65 \% ; n=35)$. The remaining group, i.e. $29.70 \%(n=30)$, obtained results ranging from 5 to 6 sten, which indicate their average level of satisfaction with life (Table 3).

Nevertheless, while analyzing the level of satisfaction with life in different groups of residence, the results were distributed differently. In a home environment, 50.98\% $(n=26)$ of the subjects reported a high level of satisfaction with life as compared to only $20 \%(n=10)$ in the nursing home. In a home environment, the percentage of low scores reached $25.49 \%(n=13)$, while in the nursing home, it equaled $44.00 \%(n=22)$. The Barthel Scale was also used to evaluate the functional fitness of residents of the nursing home and those living in a home environment, taking into consideration the scope of skills regarding handling daily activities. The mean score for the group of subjects reached 58.9 points $( \pm 31.8)$ with a median of 60 . As for the evaluation of functional fitness, more than half of the subjects $(53.47 \%$; $n=54$ ) were classified as group II, obtaining 21 to 85 points. This means that their state is referred to as "moderate to severe". Functional fitness in $25.74 \%(n=26)$ of the subjects was at a "mild" level and ranged from 86 to 100 points. The remaining $20.79 \%(n=21)$ of the subjects were classified as group III with a "very severe" state (86-100 points). Individuals with functional fitness, referred to as "moderate to severe", more often lived in a home environment $(76.47 \%$; $n=39)$ as compared to $30.00 \%(n=15)$ who lived in the nursing home (Table 4).

Satisfaction with life among people over 60 years of age living in the nursing home and a home environment, evaluated with the use of the SWLS scale, is expressed through one's satisfaction with their achievements and living conditions. Furthermore, the study focused on the correlation between the evaluation of functional fitness and the level of satisfaction with life in the groups of subjects (Table 5).

\begin{tabular}{|c|c|c|c|c|c|c|}
\hline \multirow[t]{2}{*}{ List of statements (SWLS) } & \multicolumn{2}{|c|}{$\begin{array}{l}\text { Group } 1 \text { - residents of the } \\
\text { nursing home }(n=50)\end{array}$} & \multicolumn{2}{|c|}{$\begin{array}{l}\text { Group } 2 \text { - residents staying } \\
\text { in a home environment } \\
(n=51)\end{array}$} & \multirow[t]{2}{*}{$\begin{array}{l}\text { U Mann-Whitney } \\
\text { test }\end{array}$} & \multirow[t]{2}{*}{$p$} \\
\hline & M & SD & M & SD & & \\
\hline $\begin{array}{l}\text { In many respects, my life is almost } \\
\text { ideal }(1-7)\end{array}$ & 3.7 & 1.49 & 4.7 & 1.5 & 795 & $0.001^{* * *}$ \\
\hline My living conditions are perfect (1-7) & 3.8 & 1.15 & 4.6 & 1.49 & 835 & $0.002 * *$ \\
\hline I am satisfied with my life (1-7) & 3.8 & 1.21 & 4.4 & 1.23 & 948 & $0.022^{* *}$ \\
\hline $\begin{array}{l}\text { In my life, I have achieved the most } \\
\text { important things that I wanted }(1-7)\end{array}$ & 4 & 1.17 & 4.4 & 1.37 & 1066 & 0.147 \\
\hline $\begin{array}{l}\text { If I could live my life again, I would } \\
\text { not change anything }(1-7)\end{array}$ & 3.5 & 1.36 & 4.5 & 1.48 & 803 & $0.001^{* * *}$ \\
\hline
\end{tabular}

Statistically significant: $0.01^{* *} ; p<0.001^{* * *}$.

\begin{tabular}{|c|c|c|c|c|c|c|}
\hline \multirow[t]{2}{*}{ Level of satisfaction with life } & \multicolumn{2}{|c|}{$\begin{array}{l}\text { Group } 1 \text { - residents of the nursing } \\
\text { home }\end{array}$} & \multicolumn{2}{|c|}{$\begin{array}{l}\text { Group } 2 \text { - residents staying in } \\
\text { a home environment }\end{array}$} & \multicolumn{2}{|l|}{ In total } \\
\hline & $n=50$ & $\%$ & $n=51$ & $\%$ & $n=101$ & $\%$ \\
\hline Low (1-4 sten) & 22 & 44.00 & 13 & 25.49 & 35 & 34.65 \\
\hline Average (5-6 sten) & 18 & 36.00 & 12 & 23.53 & 30 & 29.70 \\
\hline High (7-10 sten) & 10 & 20.00 & 26 & 50.98 & 36 & 35.64 \\
\hline
\end{tabular}

\begin{tabular}{|c|c|c|c|c|c|c|c|}
\hline \multirow{2}{*}{\multicolumn{2}{|c|}{ Barthel Scale }} & \multicolumn{2}{|c|}{$\begin{array}{l}\text { Group } 1 \text { - residents of the } \\
\text { nursing home }\end{array}$} & \multicolumn{2}{|c|}{$\begin{array}{l}\text { Group } 2 \text { - residents staying } \\
\text { in a home environment }\end{array}$} & \multicolumn{2}{|l|}{ In total } \\
\hline & & $n=50$ & $\%$ & $n=51$ & $\%$ & $n=101$ & $\%$ \\
\hline Group I (86-100) & "mild" state & 20 & 40.00 & 6 & 11.76 & 26 & 25.74 \\
\hline Group II (21-85) & $\begin{array}{l}\text { "moderate to severe" } \\
\text { state }\end{array}$ & 15 & 30.00 & 39 & 76.47 & 54 & 53.47 \\
\hline Group III (0-20) & "very severe" state & 15 & 30.00 & 6 & 11.76 & 21 & 20.79 \\
\hline
\end{tabular}




\begin{tabular}{|c|c|c|c|c|}
\hline \multirow[t]{3}{*}{ Barthel Scale } & \multicolumn{4}{|l|}{ SWLS } \\
\hline & \multicolumn{2}{|c|}{ Group 1 - residents of a nursing home } & \multicolumn{2}{|c|}{ Group 2 - residents staying in a home environment } \\
\hline & $\begin{array}{l}\text { Correlation of } \\
\text { r-Pearson's }\end{array}$ & $\begin{array}{l}\text { Significance } \\
p\end{array}$ & $\begin{array}{l}\text { Correlation of } \\
r \text {-Pearson's }\end{array}$ & $\begin{array}{l}\text { Significance } \\
p\end{array}$ \\
\hline "Mild" state & 0.33 & 0.15 & 0.27 & 0.59 \\
\hline "Moderate to severe" state & -0.14 & 0.60 & 0.7 & $0.0001^{* * *}$ \\
\hline „Very severe" state & 0.13 & 0.62 & 0.42 & 0.41 \\
\hline
\end{tabular}

Statistically significant: $p<0.0001^{* * *}$.

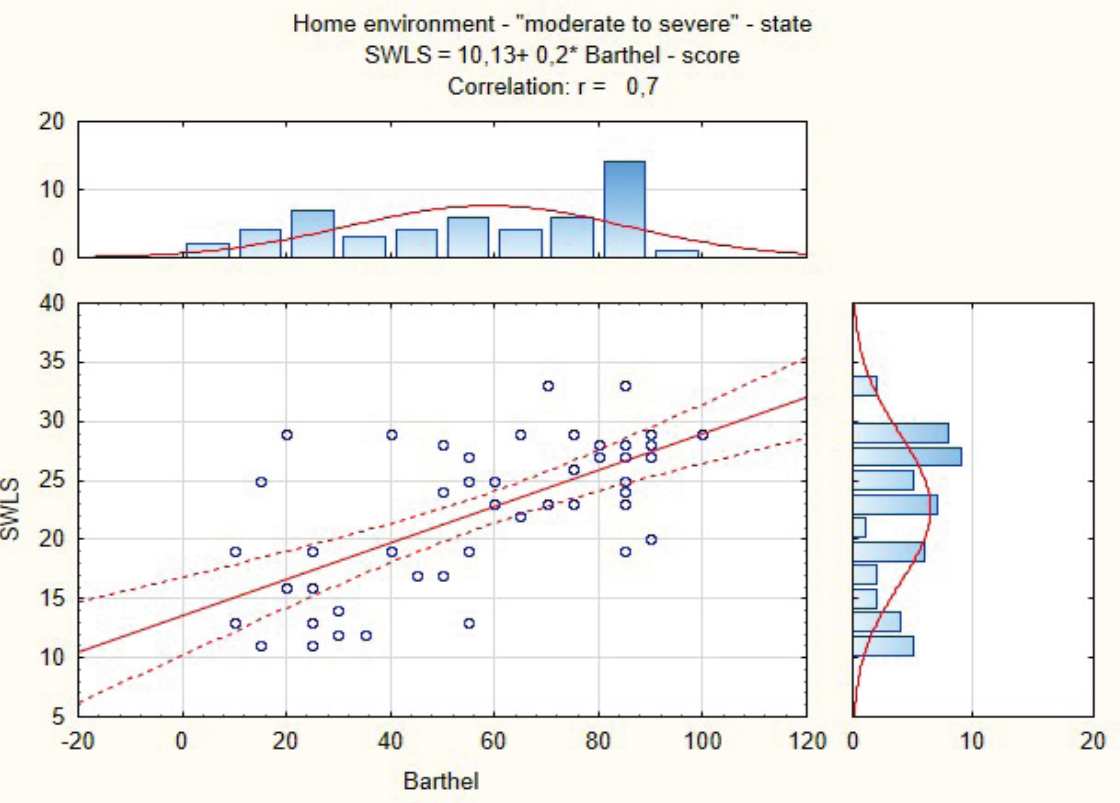

Figure 1. Correlation between a "mild to severe" state and the level of satisfaction with life among elderly subjects staying in a home environment

Also, a statistically significant (0.0001) high positive correlation $(r=0.7)$ was observed between the functional state described as "moderate to severe" among the subjects staying in a home environment and their satisfaction with life (Figure 1). This means that if the functional fitness of people staying in a home environment increases, their level of satisfaction with life also increases. On the other hand, no correlation between the evaluation of functional fitness and the level of satisfaction with life among residents of a nursing home was observed.

\section{Discussion}

Satisfaction with life as an accurate measure of wellbeing among the elderly in own research produced varied results, particularly with respect to place of residence, and favored a home environment. The mean index of satisfaction with life among all subjects reached $20.7 \pm$ 6.21, which indicated an average level of satisfaction with life. Approximately one third of subjects declared a high level of satisfaction with life; however, one third also declared it to be low. A high percentage (44\%) of residents of the nursing home reported a low level of satisfaction with life. Also, residents of the nursing home, in 4 out of 5 available statements in the SWLS questionnaire, reported statistically significant lower results than those staying in a home environment. In the research of Fraczak and Stawska, conducted on a group of 135 residents of nursing homes in Szczecin, it was determined that the majority of subjects evaluated their life as unsuccessful $(47.41 \%)$ or at least not successful in all aspects (46.67\%). Only $5.92 \%$ of the subjects evaluated their life in a positive manner, claiming that they were definitely satisfied with it [15]. In other research conducted by Jachimowicz and Kostka in the nursing home in Kalisz in 2007, in a group of 104 residents, it was revealed that those individuals who had a high sense of oness efficiency had greater satisfaction with life. As their efficiency grew, residents displayed better functional fitness with respect to basic life activities and complex actions required in their daily routine [16]. Kalfoss and Halvorsrud performed research on a group of 379 pensioners with a mean age of 73.3 , where $47.2 \%$ of the subjects shared a flat with others, $87.9 \%$ stayed at home, and $6.9 \%$ lived in nursing homes. During the course of research, it was concluded that the following had the greatest impact to quality of life: the ability to perform daily actions, mobility, sensory fitness, good health and a home environment $[17,18]$. Other researchers claim that the elderly living in a home environment with their families experience a higher quality of life than the residents of nursing homes [19]. According to Szwarc and Szyszko-Wydra, a positive appraisal of life determines a successful and positive old age [20]. Also, another important factor which affects the level of satisfaction with life among the elderly is their functional fitness. This in turn depends largely on the ageing process, illnesses, lifestyle, as well as environmental, social and psychological factors which influence the individual during their life [21]. In the research conducted by Hellström et al. in a group of 4337 Swedes over 75 years of age, among which 1247 used institutional or private care, it was revealed that the type of care does not have significant impact on the evaluation of quality of life. On the other hand, the necessity to use support while performing daily activities had a negative impact 
on the self-esteem of the subjects, which in turn lowered their general evaluation of quality of life [22]. In the international research conducted by Mozhan et al. in 23 countries, in the opinion of 7401 elderly subjects, the key factors impacting evaluation of life quality included: ability to perform daily activities, good health, sensory fitness, mobility, freedom/independence, energy [23]. Numerous studies confirm that visual or hearing disturbance experienced by the elderly limit their mobility. For elderly people with such problems, interpersonal or communication via phone or using public transport are significantly hampered. As a result, their daily functioning and independence are limited, which in turn leads to their social isolation [24-26]. In own research, a high positive correlation was also observed between the functional state described as «moderate to severe» among the subjects staying in a home environment and their level of satisfaction with life. Moreover, it was concluded that the psychomotor fitness of the elderly that allows them to per- form daily activities independently greatly determines their level of satisfaction with life.

\section{Conclusions}

1. In the researched group, the level of satisfaction with life was varied, with lower results among the residents of the nursing home, whereas for those living in a home environment, functional fitness was the key factor in its determination.

2. In programs enhancing the quality of care targeted at the elderly over 60 years of age, it is essential to take into consideration their subjective level of satisfaction with life, which constitutes a significant cognitive and practical factor in both institutional and home care.

3. It is justified to undertake actions aimed at activisation of the elderly in order to enhance their level of psychomotor fitness.

Source of funding: This work was funded by the authors' resources.

Conflict of interest: The authors declare no conflict of interests.

\section{References}

1. Zielińska-Więczkowska H, Kędziora-Kornatowska K. Determinanty satysfakcji życiowej w późnej dorosłości - w świetle rodzimych doniesień badawczych. Psychogeriatria Pol 2010; 7(1): 11-16.

2. Fidecki W, Wysokiński M, Wrońska I, et al. Jakość życia osób starszych ze środowiska wiejskiego objętych opieką długoterminową. Probl Hig Epidemiol 2011; 92(2): 221-225.

3. Timoszyk-Tomczak C, Bugajska B. Satysfakcja z życia a perspektywa przyszłościowa w starości. Opuscula Sociologica 2013; 2(4): 83-95.

4. Zielazny P, Biedrowski P, Mucha D. Późna dorosłość - okres strat czy nowych wyzwań? MONZ 2013; 19(3): $284-287$.

5. Baumann K. Jakość życia w okresie późnej dorosłości - dyskurs teoretyczny. Gerontol Pol 2006; 14(4): 165-171.

6. Volicer L, Bloom-Charette L. Enhancing the quality of life in advanced dementia. Londyn: Brunner/Mazel; 1999.

7. Maniecka-Bryła I, Bryła M. Poglądy osób w wieku 65-74 lat na temat pomyślnego starzenia. Gerontol Pol 2008; 16(2): $119-126$.

8. Juczyński Z. Narzędzia pomiaru w promocji i psychologii zdrowia. Warszawa: Pracownia Testów Psychologicznych; 2009: 106-132.

9. Kupcewicz E. Sense of self-efficacy and satisfaction with life in the opinion of student Nurses. In: Gaworska-Krzemińska A, Olszewska J, Michalik A, eds. Woman and her baby's health secretes. Pelplin: Bernardinum; 2013: 74-81.

10. Shin DC, Johnson DM. Avowed happiness as an overall assessment of the quality of life. Social Indicators Research 1978; 5 : 475-492, doi:10.1007/BF00352944.

11. Zielińska-Więczkowska H, Kędziora-Kornatowska K. Jakość życia chorych z pierwotnym nadciśnieniem tętniczym w wieku podeszłym na tle uwarunkowań zdrowotnych (cz. 2). Pielęg XXI w 2007; 2(19): 39-43.

12. Bień B. Sytuacja zdrowotna osób w podeszłym wieku. In: Grodzicki T, Kocemba J, Skalska A, eds. Geriatria z elementami gerontologii ogólnej. Gdańsk: Via Medica; 2006: 42-46.

13. Kupcewicz E, Wróblewska T, Wołosewicz I, et al. Jakość życia osób mieszkających w domu pomocy społecznej i środowisku domowym. In: Krajewska-Kułak E, Łukaszuk CR, Lewko J, et al, eds. Holistyczny wymiar współczesnej medycyny. Białystok: Uniwersytet Medyczny; 2015: 244-259.

14. Opara J. Klinimetria w neurorehabilitacji. Ocena wyników rehabilitacji neurologicznej. Warszawa: Wydawnictwo Lekarskie PZWL; 2012: 8 .

15. Frączak B, Stawska B. Stan psychospołeczny pensjonariuszy domów pomocy społecznej. Dent Med Probl 2005; 42(4): 611-618.

16. Jachimowicz V, Kostka T. Ocena poczucia własnej skuteczności u pensjonariuszy Domu Pomocy Społecznej. Gerontol Pol 2009; 17(1): 23-31.

17. Kalfoss M, Halvorsrud L. Important Issues to Quality of Life Among Norwegian Older Adults: an exploratory study. Open Nurs J 2009; 3: 44-55.

18. Szewczyczak M, Stachowska M, Talarska D. Ocena jakości życia osób w wieku podeszłym - przegląd piśmiennictwa. Now Lek 2012; 81(1): 96-100.

19. Okła W. Psychospołeczne uwarunkowania jakości życia osób starszych w rodzinach własnych i w domach opieki społecznej. In: Steuden S, Marczuk M, eds. Starzenie się a satysfakcja z życia. Lublin: KUL; 2006: 29-38.

20. Szwarc H, Szyszko-Wydra B. Ocena własnego życia a aktualna sytuacja psychospołeczna badanych osób starszych. Gerontol Pol 1999; 7(2): 33-37.

21. Strugała M, Talarska D. Ocena sprawności podstawowej osoby w wieku podeszłym z wykorzystaniem katalogu czynności życia codziennego. Fam Med Prim Care Rev 2006; 8(2): 332-335.

22. Hellström Y, Andersson M, Hallberg IR. Quality of life among older people in Sweden receiving help from informal and/or formal helpers at home or in special accommodation. Health Soc Care Comm 2004; 12(6): 504-516.

23. Mozhan A, Skevington SM, Kalfoss M, et al. The importance of facets of quality of life to older adults: an international investigation. Qual Life Res 2010; 19(2): 293-298.

24. Broe GA, Jorm AF, Creasey H, et al. Impact of chronic systemic and neurological disorders on disability, depression and life satisfaction. Int J Geriatr Pschiatry 1998; 13(10): 667-673.

25. Nourhashemi F, Andrieu S, Gillette-Guyonnet S, et al. Instrumental activities of daily living as a potential marker of frailty: a study of 7364 community-dwelling elderly women (the EPIDOS study). J Gerontol A Biol Sci Med Sci 2001; 56(7): M448-453. 
26. Hairi N, Bulgiba AQ, Cumming RG, et al. Depressive symptoms, visual impairment, and its influence on physical disability and functional limitation. J Am Geriatr Soc 2011; 59(3): 557-559.

Tables: 5

Figures: 1

References: 26

Received: 10.09.2015

Revised: 08.02.2016

Accepted: 15.02.2016

Address for correspondence:

Ewa Kupcewicz, MD, PhD

Katedra Pielęgniarstwa

Wydział Nauk Medycznych UWM

al. Żołnierska 14C

10-719 Olsztyn

Polska

Tel.: +48 89 524-61-54

E-mail: ekupcewicz@wp.pl 